\section{Maritime Cluster Attractiveness Index}

Maritime Cluster Attractiveness Index

\section{Ioannis Lagoudis}

Department of Shipping Trade and Transport, Panepistemio Aigaiou, Mytilene, Greece and Department of Maritime Studies, University of Piraeus, Piraeus, Greece

Eleftherios M. Madentzoglou

Department of Shipping Trade and Transport,

Panepistemio Aigaiou, Mytilene, Greece

Ioannis N. Theotokas

Department of Shipping Trade and Transport, Panepistemio Aigaiou, Mytilene, Greece and Department of Maritime Studies, University of Piraeus, Piraeus, Greece, and

\author{
Tsz Leung Yip
}

Department of Logistics and Maritime Studies, Hong Kong Polytechnic University, Kowloon, Hong Kong

\begin{abstract}
Purpose - The role of clusters in the development and growth of local and national economies has been extensively studied and discussed in global literature. Different methodologies are used for analysing the impact these have in national and regional economies, such as the input-output (IO) and gravity models. This paper aims to detail the methodologies present in the literature and propose a new robust theoretical framework, which facilitates the evaluation and comparison among maritime clusters in terms of attractiveness assisting stakeholders to devise strategies, which will attract companies.
\end{abstract}

Design/methodology/approach - An index is created composed of five key categories, namely, infrastructure, financing, governance, manpower and institution/legislation. For the analysis of the index, multiattribute utility theory (MAUT) is used as a tool to evaluate the importance and performance of the different attributes using both quantitative and qualitative criteria. The methodology has been tested via the use the Piraeus maritime cluster.

Findings - The framework has been tested on its robustness and friendliness to the user providing useful insights to the stakeholders. Among the results has been the importance of the finance, manpower and infrastructure attributes, which appear to promote the cluster's attractiveness. In addition, legislation and institutional partnerships, along with Government support, need to take place improve the performance of the cluster.

Research limitations/implications - A key limitation is the fact that the methodology has been tested in a single case. Applying the methodological framework in a wider sample of clusters will significantly improve the present work.

Originality/value - The proposed model takes further existing research in the field via adopting the philosophy of the World Bank's Logistics Performance Index. Among the benefits of the proposed index is that it offers the flexibility and robustness to compare among different maritime clusters globally and can be readily used as a benchmarking policy tool at national, regional and global levels at any given point in time and attribute dimension.

Keywords Index, Clusters, Attractiveness, Maritime

Paper type Research paper

(C) Pacific Star Group Education Foundation. Licensed re-use rights only.

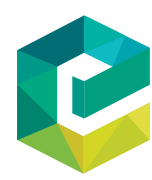

Received 6 November 2018

Revised 20 February 2019

Accepted 27 February 2019 
MABR

4,2

\section{Introduction}

Maritime industry is considered to be a basic industry with a guiding role in regional and global economic development. Business processes rely on shipping for the transportation of commodities and finished goods to the consumption and production areas (Lee et al., 2014). Extra significance is also obvious according to IMO's estimations, which suggest that 90 per cent of global trade volumes is transported by sea, implying the significant transportation role of shipping. The complex nature of the maritime industry, which includes key players, such as, ports, shipping management companies, forwarders, distribution companies and logistics companies (de Langen and Haezendonck, 2012), makes clear the necessity for a systematic and thorough performance analysis of those companies serving this industry. When companies are interconnected and have a common labour pool, they are considered to form a cluster (Porter, 1998).

The role of clusters in the development and growth of local and national economies has been extensively studied and discussed in the literature (Porter, 1998). Cluster definition varies among different nations and industries (Brett and Roe, 2010). Thus, different methodologies are used for analysing the impact these have on national and regional economies, such as the input-output (IO) models, gravity models (Pagano et al., 2012) and the Lotka-Volterra model (Zhang and Lam, 2013), as well as tools including interviews and questionnaires (Brett and Roe, 2010; Shinohara, 2010).

Delimiting a cluster starts by selecting a core cluster activity in a specific region (i.e. financial services in London). In the case of maritime clusters, core activities encompass all those related to cargo and shipping-related services between specific areas. Such activities are logistics, shipbuilding, repair, cargo handling, R\&D, ports, bunkering, shipbroking, suppliers etc. Firms share state of the art infrastructure and services, specialised customer markets, human capital resources, know-how and information. These shared resources create synergies between industrial and regional economic development. In addition, clusters fuse indigenous strengths with global best practices from firms in a variety of countries having different institutional systems (Zhao et al., 2009).

Such units and business geographically concentrated exist for decades globally, moreover on different business sectors. Policymakers have embraced the cluster concept, have identified regional clusters and have developed policies and strategies to enhance the development of clusters (Markusen, 1996). A large variety of clusters, each with different characteristics, have been identified. In the case of the maritime industry, the interrelationships between port authorities, terminal operators and suppliers of maritime services are so strong that maritime clusters are formed globally.

The strength of a maritime cluster is dependent on the significance of the interconnections among its members, with education being an essential component (Porter, 1998). Education and research are the primary sources for supply of manpower, knowledge and skills.

Europe has a mature maritime economy, which maintains a strong global position. Key to maintaining its leading position is the stimulation of entrepreneurship and innovation through scientific knowledge and a well-educated and skilled workforce. The European Network of Maritime Clusters was established in November 2005, comprising Denmark, Finland, Germany, The Netherlands, Norway, Poland, Sweden and the UK (European Network of Maritime Clusters). Given this background, this study aims at assessing the attractiveness of the maritime cluster of the port of Piraeus in Greece and identify policy implications.

Nevertheless, cluster analysis in the maritime industry lacks extended and empirical research due to the fact that it is considered as rare phenomenon rather than common practice (Rosenfield, 1997). According to Folta et al. (2006), economies of agglomeration like clusters, benefit firms in their capability to innovate and attract strategic alliances and 
private equity partners. Regional development policies and strategies play significant role in the local and national economy of the cluster improving the standard of living. A maritime cluster is a network of intensive links among firms, ports, universities, institutions and public authorities, which cooperate as a whole. Successful maritime clusters guarantee that cluster development can achieve prosperity and sustainability (Othman et al., 2011). Moreover, clusters aiming at enhancing or developing their dominance require some level of measurement and performance analysis due to the complexity of their nature.

This paper aims at identifying the factors which add value and enhance the cluster's performance and proposes a robust framework for measuring the attractiveness of a maritime cluster with the use of a Performance Index. Modern clusters are being observed as supranational phenomena needing new strategies and aspects of policy in both emerging and developing economies (Bialic-Davendra and Pavelkova, 2010). Similarly, works focusing on clusters like Silicon Valley have shown that policy-making combined with a cluster-oriented view can achieve performance optimisation (Delgado et al., 2014). Moreover, several works have also shown that clustering has a positive impact on firm performance due to the fact that it improves access to skilled workforce and specialised suppliers (Du et al., 2008).

A Maritime Performance Index will support the ability to identify the strengths and weaknesses of a maritime cluster, helping researchers and policymakers to adjust policies and strategies. The proposed performance index consists of a group of performance indicators weighted and categorised in five groups (institutional, financial, infrastructure, manpower and governance), leading to a Performance Index similar to World Bank's Logistics Performance Index. The development of such models increases the understanding of the beneficial role of clustering such as positive externalities, firm performance improvement and innovation capabilities. In the case of the maritime industry, this can lead to a better overall cluster performance such as container management improvement, loading and unloading time reduction, seamless flow of bureaucratic processes and more.

The rest of the paper is arranged as follows. Section 2 reviews the literature, Section 3 discusses the methodology and the design of the index, Section 4 presents the case of the port of Piraeus in Greece and Section 5 concludes the study.

\section{Literature review}

\subsection{Cluster definition}

Various cluster definitions exist, such as "a spatially concentrated group of firms competing in the same or related industries that are linked through vertical (buyer/supplier) and horizontal relationships (alliances, collaborations, resource sharing etc.)" (Porter, 1990). Porter did not pay much attention to geographical concentration in his early work on clusters but gradually recognised the importance of geographical proximity.

A cluster is a population, not as an entity. People cluster because of the presence of a large labour pool inside the cluster. The presence of such a labour pool reduces the cost for talent acquisition. Furthermore, such a labour pool allows for the existence of specific training and education programmes, which upgrade the quality of the labour force. This aspect is important as it implies that the internal heterogeneity of clusters has to be taken into account. The notion of a cluster population also implies that cluster population can change. Indeed, entry and exit are important mechanisms for the transformation of the cluster.

In addition, a cluster enables the geographical concentration of like-minded businesses. Firms cluster together due to the presence of suppliers and customers in a cluster. Proximity to suppliers and customers provides cost advantage due to low transportation costs, along with closer monitoring and frequent face-to-face interaction. Even though the geographical aspect is widely acknowledged, the delimitation of the relevant cluster region can be 
MABR

4,2

problematic. No matter how a cluster is geographically defined, firms in the cluster will be strongly linked with firms outside the relevant cluster region.

Finally, a cluster consists of related business units, associations and public-private organisations. Firms cluster together because of the presence of "knowledge spill-overs", which take place in clusters. Knowledge disseminates due to the frequent interaction among cluster participants and the fact that developments can be detected locally faster (de Langen, 2010). Business units participate in the cluster if they have relatively strong economic links with one or more other business units in the cluster. Associations are included in the cluster if the majority of their members are active and public-private organisations when they are strongly linked to firms in the cluster (de Langen, 2004). Because linkages are vital in the definition of clusters, these are composed of firms that can be competing or acting in a complementary way.

\subsection{Cluster theory evolution}

Cluster theory has been applied to the maritime sector over the past 10 years. Benito et al. (2003) analysed the maritime sector in Norway using Porter's framework. They quantified the characteristics of the Norwegian maritime cluster and discussed its advantages and disadvantages. De Langen (2004) analysed the collective activities of Rotterdam's port cluster and reviewed the roles of four sectors in cluster governance. Cluster analysis has become an important component for many port authorities (i.e. MIC, 2003) emphasising on the competitive advantages induced by geographic concentration. However, cluster theory does not provide insights in relation to the reasons a specific location is preferred against another for the creation of a specific cluster.

Clustering management and policy methods have been under investigation for the past three decades. However, maritime clustering has gained little academic attention in recent years. Clustering policies in agglomerating economies plays a significant role in industry development. Creative industry cluster approach is embedded, according to Chan and Zheng and Chan (2014), in two theoretical sources: cultural approach and local - regional development. Existing literature emphasises on spatial cluster analysis and functional clustering policies. The former refers to the co-existence of firms linked together due to the regional connection, while the latter focuses on the cluster as a whole, consisting of interconnected parts (firms, associations, etc.) cooperating together in promoting development (Hall, 2000). Thus, the latter analysis appears to be more valuable, assisting policymakers in developing clustering policies. Lai et al. (2014) analysed the clustering effect in terms of innovation. Innovation is one of the most important factors, making clustering research necessary for regional and individual firm development (Giuliani, 2005; Chang, 2011).

Cluster analysis has also become an important tool for regional development policies. In relation to maritime policy development, Othman et al. (2011) examined the factors linked to the performance of the cluster. They identified that a maritime cluster consists of three main sectors, namely, shipping, shipbuilding, ports and terminals. They recommend that the factors for success for a maritime cluster are location, competition, network and governance. Moreover, a factor playing significant role in a cluster's performance and liable function is the information spill-over among the co-localised firms and institutions (de Langen, 2010). De Langen (2010) also set an analytic cluster performance framework separating cluster structure and cluster governance. Based on his work, the most important factors for cluster performance are the level of agglomeration in the cluster, internal competition among firms, entry-exit barriers and heterogeneity of population. Agglomeration has three distinct drivers (Alfred, 1920), namely, linkages, labour pool and information/knowledge spill-overs. 
Internal competition has been also examined in the case of intra-port competition, indicating that ports (and maritime clusters in general) could promote innovation under specific circumstances such as multiple production models and many port service providers (Pallis and de Langen, 2006).

In terms of governance, the presence of a leader firm seams to contribute to the performance of the cluster, as leader firms further and protect the interests of the entire cluster (Albino et al., 1999). Such firms could be a terminal operator of a supply chain management provider (i.e. Maersk), creating multiplier effects and information spill-overs (de Langen, 2010). Information spill-overs among cluster members is of significant importance as they can improve and enhance innovation on firm strategies. Knowledge spill-overs are present in the cluster-making infrastructure to support innovation capabilities. Knowledge inputs may come from suppliers, customers, maritime services providers, universities and other research institutions. This provides extra weight in the significance of the geographic proximity and co-location of cluster members (Baptista and Swann, 1998). This argument is highly supported by Breschi's (1999) work, who suggests that high concentration of industries is a supporting factor for innovators to gain market power.

Systematic studies on port choice have been conducted for more than five decades. Murphy and Daley (1994) surveyed five groups, namely, port operators, shipping lines, freight forwarders, large and small shippers, with the results showing statistically significant differences in port selection criteria. Subsequent works have identified the influencing factors of port competitiveness for respective port users.

From a shipper's perspective, a number of surveys have been conducted to identify the factors influencing port selection (Tongzon and Sawant, 2007; de Langen, 2007). The common key determinants identified by the studies are location, terminal infrastructure, port efficiency and frequency of service. In addition, Nir, Lin and Liang (2003) used a multinomial logit model to analyse the shipper's choice behaviour among Taiwan's three ports, with selected variables being cost, travel time, shipping route and frequency of service.

In reference to shipping lines, both regional surveys and factor analyses have been conducted to capture the significant factors in port selection (Tongzon and Sawant, 2007; Chang et al., 2008; Yeo et al., 2008). Port charges and port services have long been considered as determinant factors for port selection. Moreover, both studies emphasised that hinterland cargo volume and connectivity are important factors in deciding port attractiveness.

From the perspective of port competition ability, Lirn et al. (2004) used the analytic hierarchy process (AHP) to reveal the port selection process of global carriers. Yang et al. (2005) applied an AHP model to analyse non-quantifiable factors and develop an index system to evaluate container port competition. In addition, there have been studies measuring the attractiveness of ports in terms of port-hinterland connectivity, aiming at identifying the factors shippers use when evaluating a port (Veldman and Buckman, 2003; Malchow and Kanafani, 2004; Malchow and Kanafani, 2001; Garcia-Alonso and SanchezSoriano, 2009).

Veldman and Buckman (2003) studied the problem of port competition from a shippers' perspective based on the routing decision. Factors affecting cargo routing, such as transportation cost, transit time, frequency of service and service quality, were quantified. Similar work has been conducted by Garcia-Alonso and Sanchez-Soriano (2009), who analysed the actual inter-port distribution of traffic to examine the port selection process. 
MABR

4,2

174
Figure 1.

The triple helix model
However, there are two major limitations in the so far works. The first limitation identified by Tongzon (2009) is that there is an inconsistency between the stated preference and the revealed preference of shipping lines. Second, supply chain services are ignored. As port attractiveness is only one component for port choice, door-to-door multimodal transportation should be given more attention.

Ports have been in the centre of the attention in more recent studies examining maritime clusters. Characteristic is the study of Zhang and Lam (2017), who examined the role of ports in maritime cluster development, using the cases of London and Hong Kong. Similar works focusing on different aspects of cluster on different locations around the globe are present such as, Panama (Pagano et al., 2016), Canada (Doloreux et al., 2015), Malaysia (Othman et al., 2011) and Japan (Shinohara, 2010).

Innovation is another dimension for clusters which is considered to be a function of key variables such as, interaction with business markets, product development and human resources (Lendel and Varmus, 2014). For a maritime cluster, innovation could be identified as the provision of effective services at low cost. Such services could be terminal management with better container handling, which eliminates delays. Empirical research such as the one by Brett and Roe (2010), where Delphi method was used to study the Great Dublin maritime transport cluster, revealed the lack of promotion strategies, the existence of strong internal competition, strong exit barriers and significant access to cluster knowledge, but with low trust levels present among cluster stakeholders. As presented in Figure 1, based on THM (Triple Helix Model), these stakeholders are (Leydesdorff and Etzkowitz, 1996):

- institutions (universities, research institutes);

- firms and enterprises (in this case shipping oriented); and

- central, regional and local government to facilitate clusters' processes.

This model is a regional development model, which describes the interactions among the different stakeholders of the cluster.

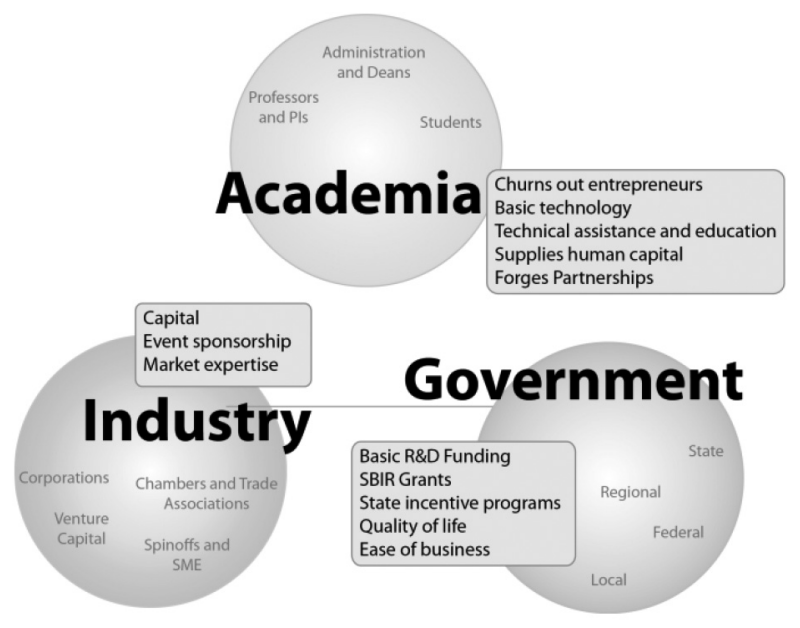

Source: Authors 
Therefore, an index similar to Leydesdorff and Etzkwitz (1996) is developed to assess the attractiveness of a maritime cluster, using the Port of Piraeus in Greece as a case study.

\section{Methodology}

The proposed framework enables cluster stakeholders to evaluate the weaknesses and strengths of a cluster, especially in highly competitive cases as is the maritime cluster, where according to Leonard and Swap (2000), skills such as management and knowledge techniques are necessary for the cluster to support its activities.

\subsection{Attractiveness index}

An attractiveness index includes four key categories:

(1) Policy and regulatory framework: Within this, the cluster exists and operates. Without a supportive and complementary policy and regulatory framework, the full potential of the cluster for high-end services will be constrained. The factors also include the environmental, sustainability and cultural elements, which encourage maritime-related firms and their workforce to operate.

(2) Institutional structure: This reflects the structural form of the cluster comprising of both public and private organisations. An institutional structure that lacks awareness, communication and collaboration is unable to maximise the economies of scope, which are inherently part of a successful cluster of high-end maritime services.

(3) Manpower: This represents the availability of skills and resources to meet the current and future needs of the maritime cluster to further develop unconstrained and create innovation and entrepreneurship.

(4) Tax and financial tools: These encourage membership, growth, resourcing and innovation within the maritime cluster.

Common goals in a cluster are set through joint activities of members (cluster actors). They are being accomplished in various areas within (i.e. common projects, research, production, services etc.), having both short-term and long-term perspective. Based on existing research, cluster activities can be found in the areas of networking, human resources, research and innovation, business cooperation and promotion, investment financing, governmental and political activities and supporting activities.

As far as the performance of a maritime cluster is concerned, several works have taken place in recent years for identifying the key sectors of the cluster. These sectors can be, ports, shipping lines, agencies, shipbuilding and repair, offshore, marine equipment, bunkering, ship chandlery, ship broking and chartering, classification societies, ship management, logistics, legal services, insurance, finance, education and training, research and development and information technology (Cullinane et al., 2007).

\subsection{Conceptual model}

The performance index created here is composed of several weighted sub-indexes, which are measurable components-indicators of cluster parts, following the philosophy of World Bank's Logistics Performance Index. A multi-attribute utility theory (MAUT) approach is applied for the purposes of this work. Multivariate techniques are considered to be more advanced and more complicated as they allow the researcher to study the behaviour of more than two variables simultaneously. Compared to other decision analysis tools, MAUT's superiority is its high level of robustness, that is its ability to analyse and formulate
Maritime Cluster Attractiveness Index 
MABR

4,2

176

problems with a level of imprecision, which is not feasible when using other methodologies (Dyer et al., 1992). Using six factors presented in Table I, MAUT is preferred to other methods such as AHP, structural equation modelling (SEM) and regression analysis (Lagoudis et al., 2006).

According to Von Winterfeldt and Edwards (1986), there are three main models of aggregation weights and single-attribute utilities as presented in Table II.

For this study, the additive model has been selected as it is suited to the purposes of the research. The total index value is calculated based on the following equation:

$$
\begin{aligned}
\mathrm{MCAI}= & (\text { Infrastructure Category Value }) \times \mathrm{W}_{1}+(\text { Finance Category Value }) \times \mathrm{W}_{2} \\
& +(\text { Governance Category Value }) \times \mathrm{W}_{3}+(\text { Manpower Category Value }) \times \mathrm{W}_{4} \\
& +(\text { Institution/Legislation Category Value }) \times \mathrm{W}_{5}
\end{aligned}
$$

where $\mathrm{W}_{\mathrm{i}}$ = the weight of each Category. The weight $\mathrm{W}_{\mathrm{i}}$ is given by the following formula based on Eckenrode (1965):

\begin{tabular}{lcccc}
\hline Factor & MAUT & A.H.P. & S.E.M. & Regression \\
\hline Easy to comprehend & $\bullet$ & $\bullet$ & $\bullet$ & $\bullet$ \\
No need of special software & $\bullet$ & $\bigcirc$ & $\bigcirc$ & $\bigcirc$ \\
Easy to apply & $\bullet$ & $\bigcirc$ & $\bullet$ & $\bigcirc$ \\
Easy questionnaire design & $\bullet$ & 0 & $\bullet$ & $\bullet$ \\
No sampling restrictions & $\bullet$ & $\bullet$ & $\bullet$ & \\
Comparison of more than two factors & & & & \\
Notes: $\bullet$ Yes; $\bigcirc$ No & & & & \\
Source: Lagoudis, Lalwani and Naim (2006) & & & &
\end{tabular}

Table I.

Comparison of methodologies

Source: Lagoudis, Lalwani and Naim (2006)

\begin{tabular}{lc}
\hline Model & Formula \\
\hline Additive with linear value function & $\mathrm{u}(\mathrm{x})=\mathrm{w} 1 \mathrm{x} 1+\mathrm{w} 2 \mathrm{x} 2+\mathrm{w} 3 \mathrm{x} 3$ \\
$\mathrm{udditive}$ & $\mathrm{u}(\mathrm{x})=\mathrm{w} 1 \mathrm{u} 1(\mathrm{x}) 1+\mathrm{w} 2 \mathrm{u} 2(\mathrm{x} 2)+\mathrm{w} 3 \mathrm{u} 2(\mathrm{x} 3)$ \\
& $+\mathrm{w} 1(\mathrm{x} 1)+\mathrm{w} 2 \mathrm{w} 2(\mathrm{x} 2)+\mathrm{w} 3 \mathrm{u} 2(\mathrm{x} 3)$ \\
Multiplicative (extended) & $+\mathrm{ww} 1 \mathrm{w} 3 \mathrm{u} 1(\mathrm{x} 1) \mathrm{u} 3(\mathrm{x} 3)$ \\
& $+\mathrm{ww} 2 \mathrm{w} 3 \mathrm{u} 2(\mathrm{x} 2) \mathrm{u} 3(\mathrm{x} 3)$ \\
& $+\mathrm{w} 2 \mathrm{w} 1 \mathrm{w} 2 \mathrm{w} 3 \mathrm{u} 1(\mathrm{x}) 1 \mathrm{u} 2(\mathrm{x} 2) \mathrm{u} 3(\mathrm{x} 3)$ \\
& $1+\mathrm{wu}(\mathrm{x})=[1+\mathrm{ww} 1 \mathrm{u} 1(\mathrm{x} 1)][1+\mathrm{ww} 2 \mathrm{u} 2(\mathrm{x} 2)]$ \\
Multiplicative (compact) & {$[1+\mathrm{ww} 3 \mathrm{u} 3(\mathrm{x} 3)]$} \\
Multi-linear & $\mathrm{u}(\mathrm{x})=\mathrm{w} 1 \mathrm{u} 1(\mathrm{x} 1)+\mathrm{w} 2 \mathrm{u} 2(\mathrm{x} 2)+\mathrm{ww} 3 \mathrm{u} 3(\mathrm{x} 3)$ \\
& $+\mathrm{w} 1,2 \mathrm{u} 1(\mathrm{x} 1) \mathrm{u} 2(\mathrm{x} 2)$ \\
& $+\mathrm{w} 1,3 \mathrm{u} 1(\mathrm{x} 1) \mathrm{u} 3(\mathrm{x} 3)$ \\
& $+\mathrm{w} 2,3 \mathrm{u} 2(\mathrm{x} 2) \mathrm{u} 3(\mathrm{x} 3)$ \\
& $+\mathrm{w} 1,2,3 \mathrm{u} 1(\mathrm{x} 1) \mathrm{u} 2(\mathrm{x} 2) \mathrm{u} 3(\mathrm{x} 3)$
\end{tabular}

Table II.

MAUT Aggregation models $(n=3)$
Notes: u: Overall value function; x: Evaluation object; xi: Measurement (level, degree) of x on attribute i; ui: Single-attribute value function; wi: Weight of attribute $i$

Source: Von Winterfeldt and Edwards (1986) 


$$
\mathrm{W}_{\mathrm{i}}=\mathrm{R}_{\mathrm{c}} / \operatorname{Sum}\left(\mathrm{R}_{\mathrm{c}}\right)
$$

Maritime Cluster

where:

$\mathrm{R}_{\mathrm{c}}=$ sum of converted ranks across judges for each criterion;

$$
\mathrm{R}_{\mathrm{c}}=\operatorname{Sum}\left(\mathrm{R}_{\mathrm{cj}}\right)
$$

in which

$\mathrm{R}_{\mathrm{cj}}=$ converted rank assigned by judge $j$ to criterion $c$.

To make clear the processes involved in weight estimations, a framework table is presented based on the set of attributes in Table III. Column 1 refers to the name of the variable, and in the second column (Normal rank), the score each variable achieves is depicted. This score is the sum of the opinions of all participants for each individual attribute. In the third column the reciprocal of normal rank is calculated. The most important variable takes the value 1 and the rest are adjusted to this variable. The last column is a rank weight based on the third column.

Based on literature, the factors that affect the performance of a maritime cluster fall in the following five categories: infrastructure, financing, governance, manpower and institution/ legislation. The evaluation of each factor is based on the mean of each attribute in relevance to the overall sub-mean value of each category (Figure 2). The value for each attribute is collected via questionnaires using a Likert scale from 1 to 5 . Each group of questions was consisted of a question measuring the performance and another question measuring the importance of each factor. For performance questions, 1 is for very low performance and 5 for very high. Respectively, for importance questions 1 stands for "not important at all" and 5 stands for "extremely important". For example, each indicator $A_{i}$ will gain a score based on the respondents' answers. Each indicator of the Category will score a mean value and the whole Category will have a total score of $P_{i}$. Overall, category scores will be weighted according to the significance each category has on the performance index.

The performance indicators, which compose the overall Cluster Performance Index, were selected based on the frequency present in the literature. Depending on the frequency of appearance, they are categorised in four groups: above ten times, seven to nine times, five and six times and one to four times. Table IV shows the performance indicators based on frequency of appearance. As seen, the cluster performance mostly depends on "soft" factors

(1)

(2)

(3)

\begin{tabular}{|c|c|c|c|}
\hline Atribbute/Indicator & Normal rank & $\begin{array}{c}\text { Reciprocal of normal } \\
\text { rank = (most imp. score) } / Y i\end{array}$ & $\begin{array}{c}\text { Rank reciprocal } \\
\text { weight }=\operatorname{Sum}(3) /(3)\end{array}$ \\
\hline X1 (indicator 1) & (Most Important Factor Score) & 1 & $0, \ldots \ldots$ \\
\hline $\mathrm{X} 2$ & $\mathrm{Y} 2$ & ...... & $0, \ldots \ldots$ \\
\hline X3 & Y3 & ..... & $0, \ldots \ldots$ \\
\hline ....... & $\ldots$ & ..... & $0, \ldots \ldots$ \\
\hline $\mathrm{X}_{\mathrm{N}}$ & Yn & & $0, \ldots$. \\
\hline TOTAL & SUM(2) & SUM(3) & 1 \\
\hline
\end{tabular}

(4)

Source: Eckenrode (1965)

Table III.

Ranking of performance indicators 
MABR

4,2

Figure 2.

Value tree of

Maritime Cluster

Performance Index

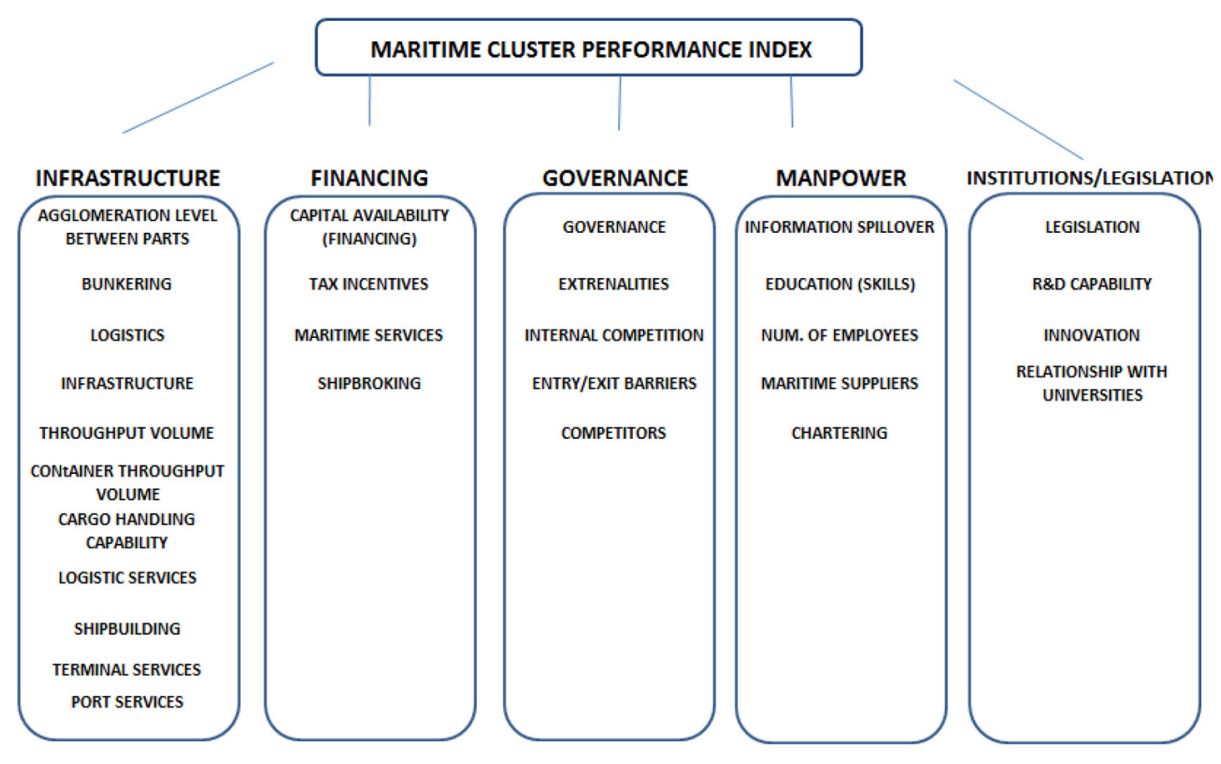

Source: Authors

Table IV.

Attributes in terms of importance 7-9

Appearance Level

$>10$

5 and 6

1-4

Agglomeration between

cluster members

Capital availability

Core technology

Bunkering

Education-skills

Logistics

Covernance-policy methods

Maritime services

(general)

Information spillover

Innovation capability

Maritime suppliers services

Social Interaction

Shipbuilding capability

Relationship with

Universities

R\&D capability

$\begin{array}{ll}\text { Externalities } & \text { Cargo handling } \\ \text { Infrastructure } & \text { Chartering }\end{array}$

Internal competition

Number of Employees

Throughput volume Entry/exit barriers Co-location

Legislation Market share

Tax incentives

Supply Chain

Management

Terminals

Source: Authors

such as people, structure and policies (Checkland, 1989). These systems allow policymakers to make use of existing infrastructure improving the overall performance.

In addition, the most important factors deal with "soft" issues capable to improving regional performance. The first group is composed of the most valuable ones, based on literature. Agglomeration between firms and cluster members relate to the maturity of the cluster and its growth capability. Governance methods and information spill-over have positive effects 
on the services offered, whereas R\&D capabilities act as enablers for innovation to a region or a cluster. This is one of the basic reasons for some clusters to excel and others to lag behind. Conclusively, education is referred as of extreme importance, enabling multiplying effects on the overall attractiveness of a cluster.

3.2.1 Infrastructure. Infrastructure and services encapsulate the "soft" factors like quality of services in a maritime cluster. This implies that performance is strongly dependent on the quality of these services in combination with the technical infrastructure in the cluster. Indicative factors are:

- Agglomeration: It promotes spatial concentration.

- Bunkering: It measures bunkering efficiency in the port.

- Logistics services: It refers to the quality of services such as warehousing and 3PL services.

- Throughput: It refers to the volumes of cargo in and out of the port.

- Shipbuilding: It refers to the shipbuilding capability of a maritime cluster.

- Information spill-over and cooperation: Experts indicate that co-operation within the cluster is important. This result is important as it provides evidence against the argument that local cooperation is not relevant, given the international nature of port related activities. Thus, a diverse local set of firms and resources is important for the performance of the cluster.

3.2.2 Finance. Finance contains the economic factors that enable firms in the cluster to operate in full efficiency. These factors provide capital and tax support to firms in the cluster. Firm leverage is strongly connected with these indicators. Among the finance factors are:

- Capital availability: It describes access to capital for a firm.

- Tax incentives: It refers to the taxation and support to firms.

- Maritime financial services: It refers to transaction and other costs among the firms of the cluster.

3.2.3 Governance. Governance in a cluster influences the structure of the cluster. Cluster governance variables are incorporated in the framework. The performance of clusters is also affected by changes in the business environment of a cluster. For instance, the development of a new energy-related technology might deeply affect the development of a chemical cluster (de Langen, 2004). Some of the most important indicators are:

- Externalities: The presence of externalities in a cluster can affect negatively the overall cluster performance.

- Internal competition: Firm competition in a cluster boosts firms' productivity level. The importance of internal competition depends on the level of external competition. When external competition is significant, the absence of internal competition does not affect the performance of the cluster. Porter's cluster research emphasises the fact that the effect of internal competition is among the strongest empirical findings (Porter, 1990).

- Entry/exit barriers prevent the entry of new firms: Legal entry barriers exist in the majority of ports, especially in the cargo handling and port services industries. In general, entry barriers are relatively high in the maritime industry due to legal or financial constraints.
Maritime

Cluster

Attractiveness Index 
MABR

4,2

180

- Presence of a leader firm: This increases the performance of a cluster, as such firms further the interests of the cluster as a whole (Albino et al., 1999). The whole cluster benefits from the presence of leader firms, due to the "multiplier effects" and "knowledge spill-overs".

3.2.4 Manpower. This category contains all the factors related to human-resource skills and education level of the workforce in the cluster. More specifically, factors such as education, number of employees, number of maritime service providers and suppliers and business culture are critical to cluster performance.

3.2.5 Institution and legislation. This category contains all the factors related to academic institutions and other institutions conducting research in cooperation with maritime firms. Among the factors within this category are the cooperation between firms and universities, willingness to innovate and R\&D capabilities. The visual presentation of cluster performance can be expressed in a spider diagram as illustrated in Figure 3.

\section{Case study}

\subsection{Sample profile}

The case study took place in the city of Piraeus in Greece. In total, 70 questionnaires were distributed to maritime related industries such as ship management companies, shipowners, shipbrokers, research institutes, maritime equipment providers and media. The criteria based on which the responding companies have been selected are:

- minimum of 10 years of presence in the Piraeus cluster; and

- to be registered in the Maritime Hellas platform. (www.maritimehellas.org).

The questionnaires were addressed to the Managing Directors or CEOs of the sampled companies assuring one response per company. The person answering the questionnaire varied depending on the policy of each company. Similar data collection approaches are present in the literature (Richardson et al., 2012; Manrai et al., 2001). The total number of responses were 30 , achieving a response rate of 42 per cent. Table $\mathrm{V}$ shows the companies, which took part in this study, with some of the respondents keeping their anonymity. The participation of academic institutions has been limited as there are less than a handful present.

Table VI presents the profile of the respondents. As seen, the majority of the respondents hold middle or executive level positions (43 per cent), with top executives representing 40 per

Figure 3.

Cluster performance depiction

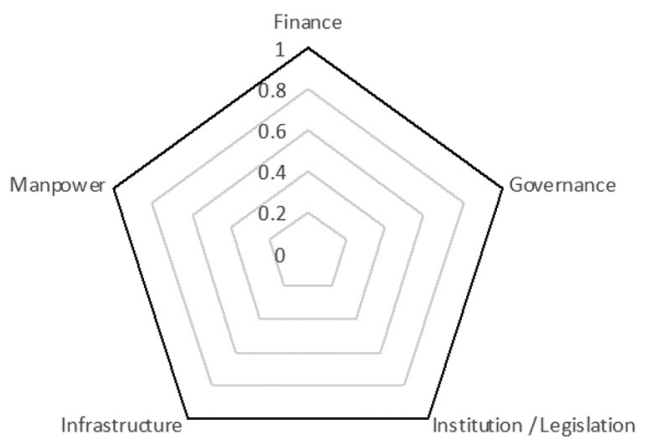

Source: Authors 
cent of the sample. Junior executives represent 17 per cent of the respondents. The average years of working experience is above 10 years of working experience in the maritime sector with 67 per cent holding a master's degree, while only 20 per cent being graduates. A small percentage (3 per cent) hold business certifications such as CFA, Chartering certification etc.

\subsection{Analysis of survey results}

4.2.1 Finance. Respondents were asked to evaluate both the performance and importance of the finance-related attributes; accessibility to capital, tax incentives, access to stock markets, cooperation with banks, government support for businesses, firm taxation, inflation, salary, insurance costs, information costs and firm expenses.

Table VII presents both the ranking among the factors and the performance of each factor based to the assigned weights. As seen, the most important factor according to the respondents is cooperation with banks, with a normal rank of importance of 130 points. This factor has also the highest performance score of 4.6 out of 5 . In terms of performance, the lowest score is assigned to government support with a score of 3.13 out of 5 . This result indicates that government and companies lack consistent and efficient cooperation. The second lowest score is assigned to inflation, which reveals that the industry pays little attention to that factor. Finally, the overall score for this category is 3.9834 .

4.2.2 Governance. Firm governance in a cluster influences the structure of the cluster and vice versa. For the purposes of this research Governance is composed of the following attributes; presence of leader firms in the cluster, entry/exit barriers, trust between cluster members, internal competition, governmental support for international exposure, presence of intermediaries, power of competitors and collective action regimes.

As presented in Table VIII, the most important factor according to the respondents is trust between firms, obtaining 122 points, followed by governmental support for

\begin{tabular}{lll}
\hline University of the Aegean & Costamare & ELVIK S.A. \\
\hline Gratia Publications & Pacific \& Atlantic & Aegean Motorway SA \\
Overseas Agency Ltd & GLOBUS Shipmanagement Corp & Lloyd's Register \\
Arcadia Shipmanagement & Trefin Tankers Ltd & Piraeus University \\
Chartworld Shipping Corporation & EVIA PETROL & GasLog \\
Stealth Gas & UPMARITIME LONDON & Vergos Marine Management S.A. \\
DYNACOM TM LTD & Psyctotherm & IASON HELLENIC SHIPPING \\
SELMA & Pireus Bank & MaranGas \\
Aluminox & HEMEXPO &
\end{tabular}

Source: Authors
Maritime Cluster Attractiveness Index

Table V. Summary of respondents

\begin{tabular}{lccllr}
\hline Position & $(\%)$ & Years of experience & $(\%)$ & Education & $(\%)$ \\
\hline Senior & 40 & $0-2$ & 20 & Bachelor's & 20 \\
Middle level & 43 & $3-5$ & 23 & Master's & 67 \\
Junior & 17 & $6-10$ & 10 & PhD & 10 \\
& & & 47 & Business qualifications & 3
\end{tabular}

Source: Authors

Table VI. Sample profile 


\section{MABR}

4,2

Attribute/indicator

Normal Reciprocal of Rank reciprocal Mean value (based Weight x value

Accessibility to capital 128

rank normal rank weight

on performance)

(4) $\times(5)$

Tax incentives and tax benefits

125

Access to stock markets

102

Cooperation with banks

130

Governmental support

\section{2}

for businesses

Firm taxation

Inflation

Salary

insurance costs

Information costs

Firm expenses

$\begin{array}{cc}122 & 0.9385 \\ 115 & 0.8846 \\ 103 & 0.7923 \\ 104 & 0.8000 \\ 103 & 0.7923 \\ 103 & 0.7923 \\ 100 & 0.7692 \\ \text { SUM } & 9.5000\end{array}$

0.1036

0.1036
0.1012

0.0826

0.9615

0.1053

4.00

3.83

3.87

0.4146

0.7846

4.60

0.3877

0.3196

0.4842

0.0988
0.0931
0.0834
0.0842
0.0834
0.0834
0.0810

3.13

0.3092

$3.80 \quad 0.3538$

$3.63 \quad 0.3027$

$\begin{array}{ll}4.37 & 0.3680\end{array}$

$\begin{array}{ll}4.20 & 0.3503\end{array}$

$4.07 \quad 0.3394$

$\begin{array}{ll}4.37 & 0.3538\end{array}$

Table VII.

Finance attributes

Source: Authors

Table VIII.

Governance attributes

\begin{tabular}{|c|c|c|c|c|c|}
\hline Attribute/indicator & $\begin{array}{l}\text { Normal } \\
\text { rank }\end{array}$ & $\begin{array}{c}\text { Reciprocal of } \\
\text { normal rank }\end{array}$ & $\begin{array}{c}\text { Rank reciprocal } \\
\text { weight }\end{array}$ & $\begin{array}{l}\text { Mean value (based } \\
\text { on performance) }\end{array}$ & $\begin{array}{l}\text { Weight x mean } \\
\text { value }(4) \times(5)\end{array}$ \\
\hline Presence of leader firms & 121 & 0.9918 & 0.136 & 3.80 & 0.5178 \\
\hline Internal Competition & 111 & 0.9098 & 0.125 & 3.33 & 0.4163 \\
\hline Entry/exit barriers & 104 & 0.8525 & 0.117 & 3.23 & 0.3783 \\
\hline Trust between firms & 122 & 1.0000 & 0.137 & 3.17 & 0.4355 \\
\hline $\begin{array}{l}\text { Governmental support for } \\
\text { international exposure }\end{array}$ & 120 & 0.9836 & 0.135 & 2.10 & 0.2838 \\
\hline Power of competitors & 109 & 0.8934 & 0.123 & 3.30 & 0.4051 \\
\hline Presence of intermediaries & 98 & 0.8033 & 0.110 & 3.07 & 0.3388 \\
\hline \multirow[t]{2}{*}{ Collective action regimes } & 103 & 0.8443 & 0.116 & 2.90 & 0.3364 \\
\hline & SUM & 7.2787 & & SUM & 3.1119 \\
\hline Source: Authors & & & & & \\
\hline
\end{tabular}

international exposure. As observed in the finance category, there is a lack of cooperation between government cluster members. In terms of trust among the different parts of a maritime cluster, it is crucial to refer that it can boost the cluster's exposure and success. The highest score was assigned to the presence of leader firms. Based on literature, the presence of leader firms is necessary in a cluster, as they can access markets smaller firms cannot. The presence of leader firms increases the performance of a cluster, as such firms actively further the interests of the cluster as a whole (Albino et al., 1999). In addition, leader firms facilitate investments improving the quality of the labour force, facilitate data exchange infrastructure and increase working standards of suppliers.

Internal competition is also a factor of high importance as it can result in innovation and increase the capability of doing "business" more efficiently. Moreover, with innovation spillovers, firms become more profitable. The overall score for the Governance category is 3.1119 .

4.2.3 Institutional legislation and innovation. As illustrated in Table IX, this category encapsulates attributes such as cooperation with Universities and research institutes, R\&D capability, willingness to innovate, cooperation with government, information spill-over, 


\begin{tabular}{|c|c|c|c|c|c|c|}
\hline Attribute/indicator & $\begin{array}{c}\text { Normal } \\
\text { rank }\end{array}$ & $\begin{array}{l}\text { Reciprocal of } \\
\text { normal rank }\end{array}$ & $\begin{array}{c}\text { Rank reciprocal } \\
\text { weight }\end{array}$ & $\begin{array}{l}\text { Mean value (based } \\
\text { on performance) }\end{array}$ & $\begin{array}{l}\text { Weight } x \text { mean } \\
\text { value }(4) \times(5)\end{array}$ & \multirow{2}{*}{$\begin{array}{r}\text { Viaritime } \\
\text { Cluster } \\
\text { Attractiveness } \\
\text { Index }\end{array}$} \\
\hline $\begin{array}{l}\text { Cooperation with Universities } \\
\text { Cooperation with }\end{array}$ & 113 & 0.8968 & 0.1171 & 2.53 & 0.2963 & \\
\hline research institutes & 120 & 0.9524 & 0.1244 & 2.57 & 0.3196 & \\
\hline R\&D capability & 120 & 0.9524 & 0.1244 & 2.7 & 0.3358 & \\
\hline Willingness to innovate & 122 & 0.9683 & 0.1264 & 3.43 & 0.4336 & 183 \\
\hline $\begin{array}{l}\text { Cooperation with Government } \\
\text { Information Spill-over }\end{array}$ & 119 & 0.9444 & 0.1233 & 2.23 & 0.2750 & \\
\hline in the Cluster & 124 & 0.9841 & 0.1285 & 3.03 & 0.3893 & \\
\hline Legislation & 126 & 1.0000 & 0.1306 & 3.27 & 0.4270 & \\
\hline Classification society & 121 & 0.9603 & 0.1254 & 3.3 & 0.4138 & Table IV \\
\hline & SUM & 7.6587 & & SUM & 2.8903 & Institution/legislation \\
\hline Source: Authors & & & & & & \\
\hline
\end{tabular}

legislation and classification societies. Legislation is the most important factor based on the results of the survey, as it assists firms to operate within the cluster. Low score is observed for the factors of cooperation with universities and cooperation with research institutes achieving a score of 2.57 and 2.53, respectively. According to the triple helix model (see Section 2 in literature review), academia is one of the three main pillars for a cluster. The results here indicate that there is a gap among these pillars, which needs to be addressed by closer collaboration between academia and industry. The overall score of this category is 2.8903, which is the lowest among the categories.

4.2.4 Infrastructure and maritime services. This category encapsulates the physical infrastructure and the services a cluster provides. For the purposes of this study the Piraeus maritime cluster services are presented in Table IX with the following attributes; Port services, Terminal services, Customs, Logistics services, Cargo handling services, Bunkering services, Shipbuilding/Repair services, Shipbroking services, and Infrastructure in Piraeus.

Based on Table X, the most important attribute is Shipbuilding/repair services, obtaining 128 points in terms of importance. Shipbuilding is one of the core businesses in a cluster, and thus these services need to be of high quality. In terms of performance this attribute achieves a score of 3.27 out of 5 . However, the highest score is obtained by Bunkering

\begin{tabular}{lccccc}
\hline Attribute/Indicator & $\begin{array}{c}\text { Normal } \\
\text { rank }\end{array}$ & $\begin{array}{c}\text { Reciprocal of } \\
\text { normal rank }\end{array}$ & $\begin{array}{c}\text { Rank reciprocal } \\
\text { weight }\end{array}$ & $\begin{array}{c}\text { Mean value (based } \\
\text { on performance) }\end{array}$ & $\begin{array}{c}\text { Weight x mean } \\
\text { value }(4) \times(5)\end{array}$ \\
\hline Port services & 120 & 0.9375 & 0.1088 & 3.00 & 0.3264 \\
Terminal services & 121 & 0.9453 & 0.1097 & 3.24 & 0.3554 \\
Customs & 116 & 0.9063 & 0.1052 & 2.50 & 0.2629 \\
Logistic services & 123 & 0.9609 & 0.1115 & 2.97 & 0.3312 \\
Cargo handling services & 127 & 0.9922 & 0.1151 & 3.23 & 0.3719 \\
Bunkering services & 124 & 0.9688 & 0.1124 & 3.60 & 0.4047 \\
Shipbuilding/Repair Services & 128 & 1.0000 & 0.1160 & 3.27 & 0.3795 \\
Shipbroking services & 116 & 0.9063 & 0.1052 & 3.73 & 0.3923 \\
Infrastructure in Piraeus & 128 & 1.0000 & 0.1160 & 3.10 & 0.3597 \\
& SUM & 8.6172 & & SUM & 3.1840
\end{tabular}

Source: Authors

Table X. Infrastructure and services attributes 
MABR

4,2

\section{4}

services with a score of 3.60 out of 5 , revealing the Port's long maritime tradition. Despite the fact that bunkering is not one of the core businesses in a maritime cluster, executives considered this to be of highest performance. Lowest performance was assigned to customs services. The overall category score is 3.1840 .

4.2.5 Manpower. Manpower refers to factors related to labour abilities and skills. Factors such as quality of education, level of productivity, teamwork ability, employee initiative and business culture are included in this category. Based on responses, the most important factor for this category is productivity with 132 points. Furthermore, as seen in Table XI, all factors of this category scored high enough, implying that Greek maritime professionals are highly qualified. More specifically, quality of education scored the highest, indicating that the manpower of the Piraeus maritime cluster is of high calibre. The overall category score is the second highest with a score 3.6508 .

\subsection{Piraeus cluster performance index}

As a next step, weights are assigned to each category to estimate the overall Index. Two scenarios are examined for this process. In the first case, equal weights are assigned to each factor, whereas in the second, weights are assigned to each of the five categories composing the index based on the rankings assigned by the respondents.

4.3.1 Index with equal weights. Index with equal weights is quite simple to conduct. There are five main factors; thus, each factor has a weight of 0.2. Then weight is multiplied with the factor value (in this case the overall score of each factor) and the final Index is the sum of these five products. Following this process, Table XII shows that the Maritime Cluster Performance Index (MCPI) for Piraeus is 3.3641.

A spider diagram is also used to depict the Index and factor scores (Figure 4).

Table XI.

Manpower attributes Source: Authors

\begin{tabular}{lccccc}
\hline Attribute/indicator & $\begin{array}{c}\text { Normal } \\
\text { rank }\end{array}$ & $\begin{array}{c}\text { Reciprocal of } \\
\text { normal rank }\end{array}$ & $\begin{array}{c}\text { Rank reciprocal } \\
\text { weight }\end{array}$ & $\begin{array}{c}\text { Mean value (based } \\
\text { on Performance) }\end{array}$ & $\begin{array}{c}\text { Weight x mean } \\
\text { value }(4) \times(5)\end{array}$ \\
\hline Quality of education & 126 & 0.9545 & 0.2000 & 3.87 & 0.7740 \\
Productivity Level & 132 & 1.0000 & 0.2095 & 3.7 & 0.7752 \\
Ability to teamwork & 126 & 0.9545 & 0.2000 & 3.73 & 0.7460 \\
Employee Initiative & 120 & 0.9091 & 0.1905 & 3.2 & 0.6095 \\
Business Culture & 126 & 0.9545 & 0.2000 & 3.73 & 0.7460 \\
& SUM & 4.7727 & & SUM & 3.6508
\end{tabular}

\begin{tabular}{lccc}
\hline Category & Value & Weight & Value $\times$ weight \\
\hline Finance & 3.9834 & 0.2 & 0.7966 \\
Governance & 3.1119 & 0.2 & 0.6223 \\
Institution/Legislation & 2.8903 & 0.2 & 0.5780 \\
Infrastructure & 3.1840 & 0.2 & 0.6368 \\
Manpower & 3.6508 & 0.2 & 0.7301 \\
Index & & 3.3641 & \\
Source: Authors & & & \\
\hline
\end{tabular}

Table XII.

Index with equal weights

Source: Authors 


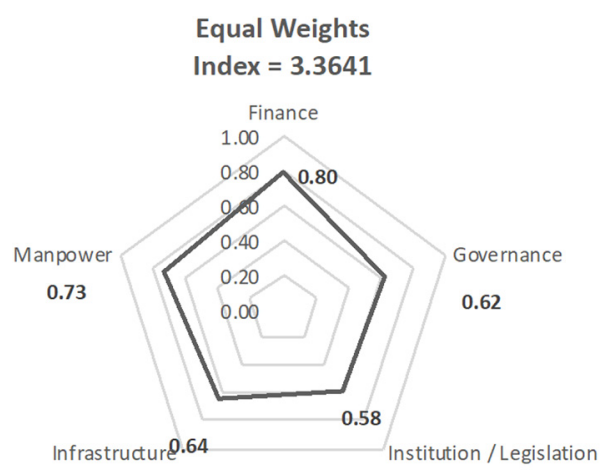

Source: Authors

\section{Maritime Cluster Attractiveness Index 185 \\ Figure 4. \\ Maritime Cluster Performance Index (equal weights)}

4.3.2 Index with non-Equal weights. When non-equal weights are assigned, weights are calculated for each factor based on the estimations of the respondents. As presented in Table XIII, the value of the weight for each factor is the outcome of the reciprocal rank. As seen, the Maritime Cluster Performance Index with non-equal weights for Piraeus is 3.3703.

A spider diagram is also used to depict the Index and factor scores (Figure 5).

\begin{tabular}{lcccc}
\hline Category & Value & Reciprocal rank sum & Weight & Value $\times$ weight \\
\hline Finance & 3.9834 & 9.5000 & 0.2511 & 1.0004 \\
Governance & 3.1119 & 7.2787 & 0.1924 & 0.5987 \\
Institution/Legislation & 2.8903 & 7.6587 & 0.2024 & 0.5851 \\
Infrastructure & 3.1840 & 8.6172 & 0.2278 & 0.7253 \\
Manpower & 3.6508 & 4.7727 & 0.1261 & 0.4606 \\
& SUM & 37.8273 & & 3.3703
\end{tabular}

Source: Authors

Table XIII. Index with AHP weights

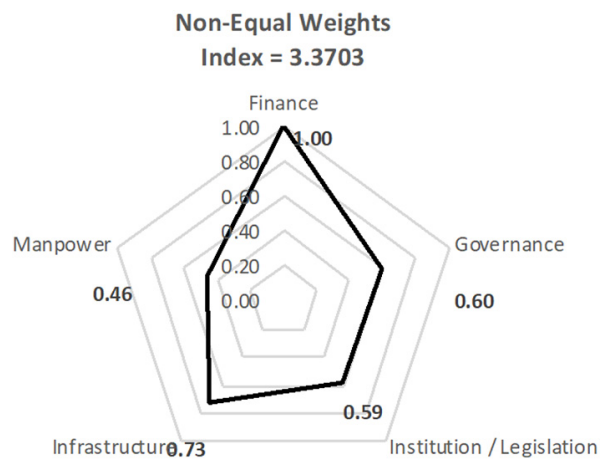

Figure 5. Maritime Cluster Performance Index (non-equal weights) 


\section{MABR}

4,2

\section{Conclusions}

This present study focuses on measuring the attractiveness of a maritime clusters via the creation of a methodological framework. The study has reviewed in depth the methodologies present in the cluster literature, emphasising on maritime clusters, and is proposing a new robust theoretical framework which facilitates the evaluation of the attractiveness of maritime clusters, assisting stakeholders to devise strategies, which will attract companies.

For the analysis of the index, MAUT is used as a tool to evaluate the importance and performance of the different attributes composing the index, namely, infrastructure, financing, governance, manpower and institution/legislation. Among the benefits of the proposed index is that it offers the flexibility and robustness to compare among different maritime clusters globally and can be readily used as a benchmarking policy tool at national, regional and global levels. In addition, its conceptual simplicity in combination with the well tested MAUT methodology, which is used for the analysis of the collected data, makes it a comprehensive tool for both policy and industry stakeholders in evaluating the cluster's performance at any given point in time and attribute dimension. Furthermore, the active participation of the stakeholders via the use of questionnaires provides a collective perception of the cluster's status.

With the use the Piraeus maritime cluster case, the framework has been tested in its robustness and friendliness to the user, providing useful insights to the stakeholders. Among the results has been the importance of the finance, manpower and infrastructure attributes, which appear to promote the cluster's attractiveness. In addition, legislation and institutional partnerships, along with government support, need to take place improve the performance of the cluster.

The fact that the authors had the opportunity to use only one case study to test the methodological framework is among the limitations of the study. Applying and testing the methodological framework in a wider sample of clusters to identify weaknesses and shortfalls will significantly improve the present work. An additional element that can further improve this work is to explore and compare MAUT, which has been justified as the proper tool for data analysis here, with other tools available in the literature (i.e. AHP, SEM and regression) for evaluating and measuring the under-investigation attributes. This comparison will provide further insights for the improvement of the methodology itself.

\section{References}

Albino, V., Garavelli, A.C. and Schiuma, G. (1999), "Knowledge transfer and inter-firm relationships in industrial districts: the role of the leader firm", Technovation, Vol. 19 No. 1, pp. 53-63.

Alfred, M. (1920), Principles of Economics, Macmillan and Co., London.

Baptista, R. and Swann, P. (1998), "Do firms in clusters innovate more?", Research Policy, Vol. 27 No. 5, pp. 525-540.

Benito, G.R.G., Berger, E., de la Forest, M. and Shum, J. (2003), “A cluster analysis of the Maritime sector in Norway”, International Journal of Transport Management, Vol. 1 No. 4, pp. 203-215.

Bialic-Davendra, M. and Pavelkova, D. (2010), “Cluster concept development-a case study from Poland".

Breschi, S. (1999), "Spatial patterns of innovation: evidence from patent data", The Organization of Economic Innovation in Europe, pp. 71-102.

Brett, V. and Roe, M. (2010), "The potential for the clustering of the Maritime transport sector in the greater Dublin region", Maritime Policy and Management, Vol. 37 No. 1, pp. 1-16. 
Chang, Y.C. (2011), "Maritime clusters: what can be learnt from South West of England", Ocean and Coastal Management, Vol. 54 No. 6, pp. 488-494.

Chang, Y.T., Lee, S.Y. and Tongzon, J.L. (2008), "Port selection factors by shipping lines: different perspectives between trunk liners and feeder service providers", Marine Policy, Vol. 32 No. 6 , pp. 877-885.

Checkland, P.B. (1989), "Soft systems methodology", Human Systems Management, Vol. 8 No. 4, pp. 273-289.

Cullinane, K., Yap, W.Y. and Lam, J.S.L. (2007), “The port of Singapore and its governance structure”, Research in Transportation Economics, Vol. 17, pp. 285-310.

De Langen, P. (2004), “Governance in seaport clusters”, Maritime Economics and Logistics, Vol. 6 No. 2, pp. 141-156.

De Langen, P.W. (2007), "Port competition and selection in contestable hinterlands; the case of Austria", European Journal of Transport and Infrastructure Research, Vol. 7 No. 1, pp. 1-14.

De Langen, P.W. and Haezendonck, E. (2012), "Ports as clusters of economic activity", The Blackwell Companion to Maritime Economics, pp. 639-654.

Delgado, M., Porter, M.E. and Stern, S. (2014), "Clusters, convergence and economic performance", Research Policy, Vol. 43 No. 10, pp. 1785-1799.

Doloreux, D., Shearmur, R. and Figueiredo, D. (2015), “Québec's coastal Maritime cluster: its impact on regional economic development, 2001-2011”, Marine Policy, Vol. 71, pp. 201-209.

Du, J., Lu, Y. and Tao, Z. (2008), "Economic institutions and FDI location choice: evidence from US multinationals in China", International Journal of Finance and Economics, Vol. 36 No. 3, pp. 92-107.

Dyer, J.S., Fishburn, P.C., Steuer, R.E., Wallenius, J. and Zionts, S. (1992), "Multiple criteria decision making, multi-attribute utility theory: the next ten years", Management Science, Vol. 38 No. 5, pp. 645-654.

Eckenrode, R.T. (1965), “Weighting multiple criteria”, Management Science, Vol. 12 No. 3, pp. 180-192.

Folta, T.B., Cooper, A.C. and Baik, Y.S. (2006), "Geographic cluster size and firm performance”, Journal of Business Venturing, Vol. 21 No. 2, pp. 217-242.

Garcia-Alonso, L. and Sanchez-Soriano, J. (2009), "Port selection from a hinterland perspective", Maritime Economics and Logistics, Vol. 11 No. 3, pp. 260-269.

Giuliani, E. (2005), "Cluster absorptive capacity: why do some clusters forge ahead and others lag behind?", European Urban and Rregional Studies, Vol. 12 No. 3, pp. 269-288.

Hall, S.P. (2000), “Creative cities and economic development”, Urban Studies, Vol. 37 No. 4, pp. 639-649.

Lai, Y.L., Hsu, M.S., Lin, F.J., Chen, Y.M. and Lin, Y.H. (2014), "The effects of industry cluster knowledge management on innovation performance", Journal of Business Research, Vol. 67 No. 5, pp. 734-739.

Lagoudis, I.N., Lalwani, C.S. and Naim, M.M. (2006), "Ranking of factors contributing to higher performance in the ocean transportation industry: a multi attribute utility theory approach", Maritime Policy and Management, Vol. 33 No. 4, pp. 345-369.

Lee, C.B., Wan, J., Shi, W. and Li, K. (2014), “A cross-country study of competitiveness of the shipping industry", Transport Policy, Vol. 35, pp. 366-376.

Lendel, V. and Varmus, M. (2014), "Evaluation of the innovative business performance", Procedia Social and Behavioral Sciences, Vol. 129, pp. 504-511.

Leonard, D. and Swap, W. (2000), "Gurus in the garage", Harvard Business Review, Vol. 78 No. 6, pp. $71-78$.

Leydesdorff, L. and Etzkowitz, H. (1996), "Emergence of a triple helix of university-industrygovernment relations", Science and Public Policy, Vol. 23 No. 5, pp. 279-286. 
MABR

4,2

Lirn, T.C., Thanopoulou, H.A., Beynon, M.J. and Beresford, A.K.C. (2004), “An application of AHP on transhipment port selection: a global perspective", Maritime Economics and Logistics, Vol. 6 No. 1, pp. 70-91.

Malchow, M. and Kanafani, A. (2001), "A disaggregate analysis of factors influencing port selection", Maritime Policy and Management, Vol. 28 No. 3, pp. 265-277.

Malchow, M.B. and Kanafani, A. (2004), “A disaggregate analysis of port selection”, Transportation Research Part E, Vol. 40 No. 4, pp. 317-337.

Manrai, L.A., Manrai, A.K. and Lascu, D.N. (2001), "A country-cluster analysis of the distribution and promotion infrastructure in Central and Eastern Europe”, International Business Review, Vol. 10 No. 5, pp. 517-549.

Murphy, P.R. and Daley, J.M. (1994), “A comparative analysis of port selection factors”, Transportation Journal, Vol. 34 No. 1, pp. 15-21.

Nir, A.S., Lin, K. and Liang, G.S. (2003), "Port choice behaviour: from the perspective of the shipper", Maritime Policy and Management, Vol. 30 No. 2, pp. 165-173.

Othman, M.R., Bruce, G.J. and Hamid, S.A. (2011), "The strength of Malaysian Maritime cluster: the development of Maritime policy", Ocean and Coastal Management, Vol. 54 No. 8, pp. 557-568.

Pagano, A.M., Light, M.K., Sanchez, O.V., Ungo, R. and Tapiero, E. (2012), "Impact of the Panama canal expansion on the panamanian economy", Maritime Policy and Management, Vol. 39 No. 7 , pp. 705-722.

Pagano, A., Wang, G., Sánchez, O., Ungo, R. and Tapiero, E. (2016), “The impact of the Panama canal expansion on panama's Maritime cluster", Maritime Policy and Management, Vol. 43 No. 2, pp. 164-178.

Porter, M.E. (1998), "Clusters and the new economics of competition”, Harvard Business Review,

Richardson, C., Yamin, M. and Sinkovics, R.R. (2012), "Policy-driven clusters, interfirm interactions and firm internationalisation: some insights from Malaysia's multimedia super", International Business Review, Vol. 21 No. 5, pp. 794-805.

Rosenfield, S.A. (1997), "Bringing business clusters into the mainstream of economic development", European Planning Studies, Vol. 5 No. 1, pp. 3-23.

Shinohara, M. (2010), "Maritime cluster of Japan: implications for the cluster formation policies", Maritime Policy and Management, Vol. 37 No. 4, pp. 377-399.

Tongzon, J.L. (2009), "Port choice and freight forwarders", Transportation Research Part E, Vol. 45 No. 1, pp. 189-195.

Tongzon, J.L. and Sawant, L. (2007), "Port choice in a competitive environment: from the shipping lines' perspective”, Applied Economics, Vol. 39 No. 4, pp. 477-492.

Veldman, S.J. and Buckman, E.H. (2003), "A model on container port competition: an application for the West European container hub-ports", Maritime Economics and Logistics, Vol. 5 No. 1, pp. 3-22.

Von Winterfeldt, D. and Edwards, W. (1986), Decision Analysis and Behavioural Research, Cambridge University Press, Cambridge.

Yang, Y.B., Yang, Z.Z., Yang, Z. and Zuo, Z. (2005), "Evaluation of competition ability and market share for container port", Proceedings of the Eastern Asia Society for Transportation Studies, Vol. 5, pp. 2483-2493.

Yeo, G., Roe, M. and Dinwoodie, J. (2008), "Evaluating the competitiveness of container ports in Korea and China", Transportation Research Part A, Vol. 42 No. 6, pp. 910-921.

Zhang, W. and Lam, J.S.L. (2013), "Maritime cluster evolution based on symbiosis theory and LotkaVolterra model", Maritime policy and Management, Vol. 40 No. 2, pp. 161-176.

Zhang, W. and Lam, J.S.L. (2017), "An empirical analysis of Maritime cluster evolution from the port development perspective - cases of London and Hong Kong”, Transportation Research Part A, Vol. 105, pp. 219-232. 
Zheng, J. and Chan, R. (2014), "The impact of 'creative industry clusters' on cultural and creative industry development in Shanghai”, City, Culture and Society, Vol. 5 No. 1, pp. 9-22.

Maritime Cluster

\section{Further reading}

De Langen, P.W. (2002), "Clustering and performance: the case of Maritime clustering in Netherlands", Maritime Policy and Management, Vol. 29 No. 3, pp. 209-221.

De Langen, P.W. and Pallis, A.A. (2006), "Analysis of the benefits of intra port competition", International Journal of Transport Economics, Vol. 33 No. 1, pp. 69-85.

Johansson, H.J., McHugh, P., Pendlebury, A.J. and Wheeler, W.A. (1993), Business Process Reengineering: Breakpoint Strategies for Market Dominance, John Wiley and Sons, Hoboken, NJ.

Karahan, C.B. and Kirval, L. (2018), "Clustering potential of Istanbul Maritime sector", Maritime Business Review, Vol. 3 No. 3, pp. 314-336.

KPMG Hong Kong (2007), "Hong Kong tax competitiveness series: the shipping industry”.

Maritime Hellas (2016), available at: www.maritimehellas.org/en/search

Marshall, A. (1920), Principles of Economics, Macmillan and Co., London.

Zahra, S.A., Ireland, R.D. and Hitt, M.A. (2000), "International expansion by new venture firms: International diversity, mode of market entry, technological learning, and performance", Academy of Management Journal, Vol. 43 No. 5, pp. 925-950.

\section{Corresponding author}

Ioannis Lagoudis can be contacted at: ilagoudis@unipi.gr

For instructions on how to order reprints of this article, please visit our website: 